\title{
Cherry tomato yield in greenhouses with different plastic covers
}

\author{
Ester Holcman $^{1^{*}}$ Paulo Cesar Sentelhas ${ }^{1}$ Simone da Costa Mello ${ }^{2}$
}

\begin{abstract}
'Departamento de Engenharia de Biossistemas, Escola Superior de Agricultura "Luiz de Queiroz" (ESALQ), Universidade de São Paulo (USP), CP 09, 13418-900, Piracicaba, SP, Brasil. E-mail: esterholcman@yahoo.com.br. *Corresponding author.

2Departamento de Produção Vegetal, Escola Superior de Agricultura "Luiz de Queiroz" (ESALQ), Universidade de São Paulo (USP), Piracicaba, SP, Brasil.
\end{abstract}

\begin{abstract}
The objective of the present study was to evaluate the influence of different plastic covers on microclimate and cherry tomato yield in greenhouses. The experiments were carried out in Piracicaba, state of São Paulo (Brazil), during three growing periods (2008/2009/2010). A greenhouse was divided in: Environment I (EI) - covered with plastic film anti-UV and thermo-reflective shading screen, and Environment II (EII) - covered with diffusive plastic film; monitored with automatic weather sensors; and cultivated with cherry tomato ('Sweet Grape' and 'Sweet Million'). Use of diffusive plastic in greenhouses provides a better inside distribution of solar energy without causing major changes in air temperature and relative humidity, resulting in higher yield ( $\left.\mathrm{kg} \mathrm{plant}^{-1}\right)$, fruits quantity (number plant ${ }^{-1}$ ) and fruits average weight than those obtained under thermo-reflective shading screen.

Key words: 'Sweet Grape', 'Sweet Million', diffusive plastic, solar radiation.
\end{abstract}

Produção de tomate cereja em ambientes protegidos com diferentes coberturas plásticas

RESUMO: $O$ objetivo do presente estudo foi avaliar a influência de diferentes coberturas plásticas no microclima e rendimento do tomate cereja em casa-de-vegetação. Os experimentos foram realizados em Piracicaba, Estado de São Paulo, durante três períodos de produção (2008/2009/2010). A casa-de-vegetação foi dividida em Ambiente I (EI) - coberto com filme plástico anti-UV e tela de sombreamento termorefletora, e Ambiente II (EII) - coberto com filme plástico difusor; monitorados com sensores meteorológicos automáticos; e cultivados com tomate cereja ('Sweet Grape'e 'Sweet Million'). O uso do plástico difusor em casas-de-vegetação proporcionou melhor distribuição da energia solar sem causar grandes mudanças na temperatura e umidade relativa do ar, resultando em maiores rendimento ( $\mathrm{kg}$ planta ${ }^{-1}$ ), quantidade de frutos (número planta-1) e peso médio dos frutos do tomateiro, em comparação ao ambiente coberto com tela termo-refletora. Palavras-chave: 'Sweet Grape', 'Sweet Million', plástico difusor, radiação solar.

\section{INTRODUCTION}

The production of specialty tomatoes is increasing (SENTO-SÉ et al., 2014) mainly because the consumers are looking for fruits with different shapes, sizes, colors and with flavors different from the conventional cultivars. Cherry tomato fruits (Lycopersicon esculentum var. cerasiforme), round, similar to a cherry juicy and meaty berry, red when ripe, bigger than $1.5 \mathrm{~cm}$ in diameter (SILVA \& GIORDANO, 2000), has an excellent consumer acceptance due to its high sweetness (PRECZENHAK et al., 2014), among other organoleptic characteristics superior to the traditional tomato fruits (PINHEIRO,
2016). In addition, market value of the cherry tomato is, on average, two to three times higher than other varieties (ARAUJO et al., 2013), which causes great interest from greenhouse producers (SOARES et al., 2005) being a growing and promising market in Brazil (PINHEIRO, 2016).

Greenhouse favors the establishment of optimal conditions for cherry tomatoes growth, as it allows the partial control of climatic variables, reducing the effect of seasonality, encouraging more balanced supply over months (SILVA et al., 2014) and the highest final yield and fruit quality (MAHAJAN \& SINGH, 2006). By virtue of the benefits offered, cultivation in greenhouses has increased in recent years, 
especially in the South and Southeast of Brazil (REIS et al., 2013). According to the Brazilian Committee for the Development and Application of Plastics in Agriculture (COBAPLA), Brazil has 22.000 hectares of protected crops (tunnels and greenhouses), in which vegetables, flowers and nurseries are produced. Half of this area, about 11 thousand hectares are located in the state of São Paulo (REBOUÇAS et al., 2015).

Air temperature reduction is one of the tomato greenhouses main objectives (ROSALES et al., 2006), since elevated temperatures resulted from high light intensity can severely limit productivity and nutritional quality of this crop (ADAMS et al., 2001). To this end, shading screens are the most used option (SERRANO et al., 2001), principally the thermoreflective screens, which have the ability to reduce the sensible heat accumulated inside the greenhouses by the incident solar radiation reflection (GUISELINI et al., 2010). However, the use of shading screens can restrict the photosynthetically active radiation quantity required by the crop (GARCÍA et al., 2011), which may compromise the tomato final yield.

The type of material used as covering in greenhouses has important role for defining the microclimate according to its transmissivity (FINCH et al., 2004), also affecting other energy balancecomponents, as sensible and latent heatflows (STANGHELLINI et al., 2011), as well as transpirations and photosynthetic processes (FERRARI \& LEAL, 2015). Currently, new materials have been developed in order to promote greater quality of the solar radiation transmitted into the greenhouses. Composed by microscopic particles that spread the light in all directions, diffusive plastic is efficiently penetrating through the plant canopy extracts. During sunny days, greenhouses covered with diffusive plastic film can have three to four times more diffuse radiation than outside (BAILLE et al., 2003), causing less sharp shadow projection than outside. Furthermore, depending on the diffusive plastic composition, the photosynthetically active radiation proportion transmitted into the greenhouse can be equal or greater compared to a transparent plastic film (SERRANO et al., 2001).

The choice of the greenhouses cover material is essential for optimizing crop production. A better understanding about the interactions between environment and tomato fruit yield and quality is still lacking (ROSALES et al., 2011). Considering that greenhouse cover has a major influence on the microclimate for the crops, the objective of this study was to evaluate and compare the effects of different types of covers on environmental conditions inside greenhouses and their effects on yield of two cherry tomatoes cultivars.

\section{MATERIALS AND METHODS}

The field experiments were carried out in a greenhouse, located at Piracicaba, State of São Paulo, Brazil (2242’40” S, 47³7’30” W, and $546 \mathrm{~m}$ altitude; Köppen classification Cwa). The experiments were performed during three tomato (Solanum lycopersicum var. cerasiforme) growing seasons: from 19 Oct. 2008 to 06 Jan. 2009; from 28 Mar. to 17 Sept. 2009; and from 09 Jun. to 07 Dec. 2010. The greenhouse had $50 \mathrm{~m}$ of length, $7 \mathrm{~m}$ of width, $4 \mathrm{~m}$ of height (north-south direction), divided in two environments: Environment I (EI) - covered with low-density polyethylene film (solar radiation (SR) transmissivity: 80\%) associated with thermoreflective screen (SR transmissivity: 57-60\%), installed internally at the ceiling height; Environment II (EII) - covered with a diffusive plastic film (SR transmissivity: $60 \%$ ). Sides of the greenhouse were covered with black shading screen (50\%), fixed throughout the experimental period.

Inside the environments, two cherry tomato cultivars were grown in soil covered with black mulching: 'Sweet Grape' and 'Sweet Million'. The spacing adopted was $0.5 \mathrm{~m}$ between plants and $1.2 \mathrm{~m}$ between lines. Wire strands were installed parallel to the ground ( 0.5 and $2.2 \mathrm{~m}$ height), among which were tied plastic ribbons for tomato branches trellising system. The higher wire strand delimited the maximum canopy height of the crop, between 2.2 and $2.3 \mathrm{~m}$. Pruning were performed weekly, in which side shoots higher than $5 \mathrm{~cm}$ of length were removed. The first bud before the first flower was preserved to be the second rod. Plants fertirrigation was applied by drip irrigation system. Stock solutions for vegetative (Solution 1) and reproductive (Solution 2) periods were: $(06 \mathrm{~N}-12 \mathrm{P}-36 \mathrm{~K}) 500 \mathrm{~g} \mathrm{~L}^{-1}$; calcium nitrate $600 \mathrm{~g} \mathrm{~L}^{-1}$; potassium nitrate $450 \mathrm{~g} \mathrm{~L}^{-1}$; magnesium nitrate $90 \mathrm{~g} \mathrm{~L}^{-1}$; monoammonium phosphate $60 \mathrm{~g} \mathrm{~L}^{-1}$; monopotassium phosphate $100 \mathrm{~g} \mathrm{~L}^{-1}$; micronutrients $10 \mathrm{~g} \mathrm{~L}^{-1}$ (Solution 1); calcium nitrate $451 \mathrm{~g} \mathrm{~L}^{-1}$; monopotassium phosphate $179 \mathrm{~g} \mathrm{~L}^{-1}$; potassium sulphate $388 \mathrm{~g} \mathrm{~L}^{-1}$; magnesium sulfate $263 \mathrm{~g} \mathrm{~L}^{-1}$; micronutrients $40 \mathrm{~g} \mathrm{~L}^{-1}$ (Solution 2).

The experimental design was a randomized complete block design. Each block consisted of four treatments in a factorial design $2 \times 2$, referring the 2 cultivars ('Sweet Grape' 
and 'Sweet Million') and the 2 environments (EI and EII), with 5 repetitions of these blocks. Each treatment consisted of 10 plants and the 6 central plants were evaluated to yield per plant $(\mathrm{kg}$ fruit plant $\left.^{-1}\right)$, fruit weight $\left(\mathrm{g}\right.$ fruit $\left.^{-1}\right)$, fruits number per plant, fruit transversal and longitudinal diameters, and fruit size (small and large). Fruits with transversal and longitudinal diameters $\leq 2.0 \mathrm{~cm}$ and $\leq 2.5 \mathrm{~cm}$ (cv. 'Sweet Grape') and $\leq 2.2 \mathrm{~cm}$ and $\leq 2.2 \mathrm{~cm}$ (cv. 'Sweet Million'), respectively, were considered small. Plants were conducted with an average of 10 bunches and were conducted 7 harvests in each season. For the biometric variables, results were submitted to variance analysis and the comparisons among the averages were done by Tukey's Standard range test at 5\% of significance, using the GLM procedures of SAS, version 9.3 (Statistical Analysis Software). Micrometeorological data were obtained with one automatic sensor for each meteorological variable, installed in the center of each environment: air temperature $-\mathrm{T}$, and relative humidity $-\mathrm{RH}$ (HMP35, Vaisala), $1.5 \mathrm{~m}$ height above the ground; global solar radiation - SR (CM3, Kipp \& Zonen) and photosynthetically active radiation - PAR (LI190SB, Licor), $2.5 \mathrm{~m}$ height above the ground. Sensors were connected to a datalogger CR10x model (Campbell Sci.), which continuously recorded with averages being computed every 15 minutes. The micrometeorological averages were compared by Kruskal Wallis test (Assistat Software). For a better analysis, the graphs were elaborated with the average of every six days for each meteorological variable.

\section{RESULTS AND DISCUSSION}

The incoming solar radiation (SR) under plastic anti-UV + thermo-reflective screen (EI) and diffusive plastic (EII) were lower than the data obtained in outside environment (Eout) for all experimental years due to the reflection and absorption processes by the plastic coverings. SR varied greatly during the growth periods of tomato (Figure 1). The EI allowed 38.8, 31.4 and $27.9 \%$ of SR transmissivity and $32.3,28.8$ and $27.1 \%$ of photossyntetically active radiation (PAR) transmissivity, in 2008, 2009 and 2010, respectively. Values of transmissivity obtained under EII, were $62.9,43.8,39.2 \%(\mathrm{SR})$ and $64.5,55.8$ and $52.1 \%$ (PAR). SR and PAR in EII were, on average, 62.1, 39.5 and $40.3 \%$ (SR) and 100, 93 and $92.3 \%$ (PAR) higher than those observed in the EI. Despite the EII environment have allowed higher solar energy availability to the tomato plants than EI, the SR under EII was lower than $8.4 \mathrm{MJ} \mathrm{m}^{-2}$ day $^{-1}$ for 2009 and 2010. According to FAO (1990), 8.4MJ m ${ }^{-2}$ day $^{-1}$ is enough to ensure minimal production of photo-assimilates required for plant maintenance.

Typically, inside the greenhouses the air temperature is higher than outside, because the partial limitation of natural air convection movement inside the environment and the partial closing of greenhouses walls with screens, restricting the gas and sensible heat exchanges with outside (DUARTE et al., 2011). This fact was also observed in the present study (Figure 2). However, the temperature differences, for maximum and minimum averages, were very small. The minimum air temperature (Tmin) differences between EI and EII were, on average, about 0.3 to $0.9^{\circ} \mathrm{C}$ in all years (Figure 2). For maximum air temperature (Tmax), the differences varied from 0.7 to $1.5^{\circ} \mathrm{C}$. In relation to outside, the $\mathrm{T}$ differences were a little higher, about 0.1 to $1.8^{\circ} \mathrm{C}$, with inside temperature higher than outside, as also observed by FERRARI \& LEAL (2015).

Figure 2 also showed that outside RH was always higher than that measured inside the greenhouses. These results were expected, since the inside temperatures were always slightly higher than outside, making saturated vapor pressure higher and, consequently, RH lower. In all environments average maximum $\mathrm{RH}$ was close to $100 \%$. Small differences for $\mathrm{T}$ and $\mathrm{RH}$ comparing inside and outside environments are associated to the ceiling height and use of screens in the walls, favoring the air circulation, resulting in less accumulation of sensible heat nearby the sensors and less retention of water vapor by the plastic cover.

Generally, the $\mathrm{T}$ considered tolerable for the tomato growth and development is between 10 and $34^{\circ} \mathrm{C}$ (SILVA \& GIORDANO, 2000; ALVARENGA, 2004). The Tmin during the growth periods varied strongly (Figure 3 ). In 2008, the Tmin ranged between 10.6 and $20.1{ }^{\circ} \mathrm{C}$, while in 2009 and 2010 the values ranged from 8.2 to $19.8^{\circ} \mathrm{C}$ and from 9.4 to $22.3^{\circ} \mathrm{C}$, respectively. Tmin lower than $10^{\circ} \mathrm{C}$ was observed during 26 days in 2009 and only in 5 days of 2008. This fact is responsible for the lower yield obtained in 2009 when compared to 2008. The values of Tmax varied from 23.6 to $32.5^{\circ} \mathrm{C}, 20.6$ to $31.6^{\circ} \mathrm{C}$ and 24.5 to $34.5^{\circ} \mathrm{C}$ respectively in 2008 , 2009 and 2010 . The Tmax above $34^{\circ} \mathrm{C}$, admitted by ALVARENGA (2004) as the limit for tomatoes, were 


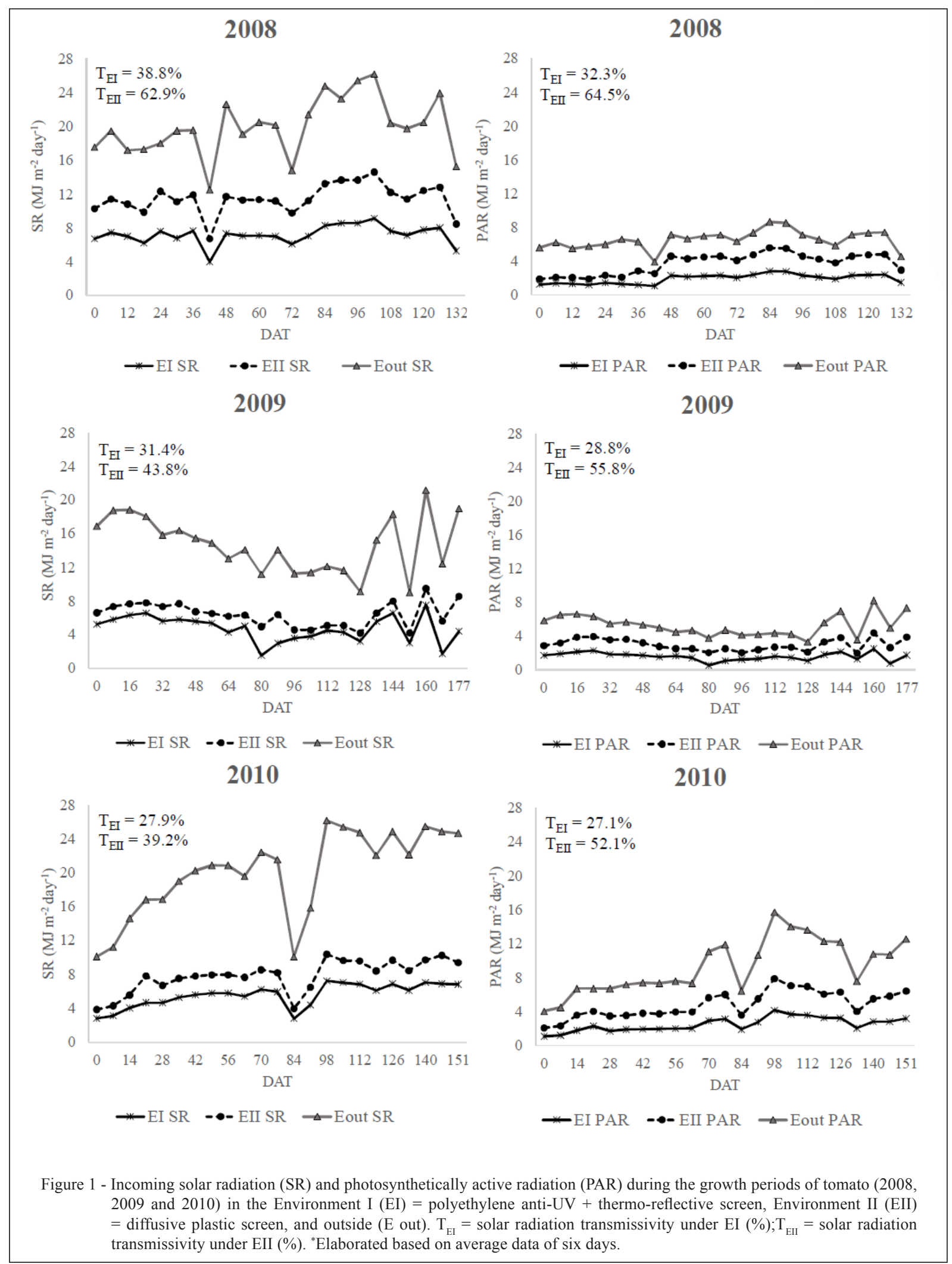

Ciência Rural, v.47, n.10, 2017. 

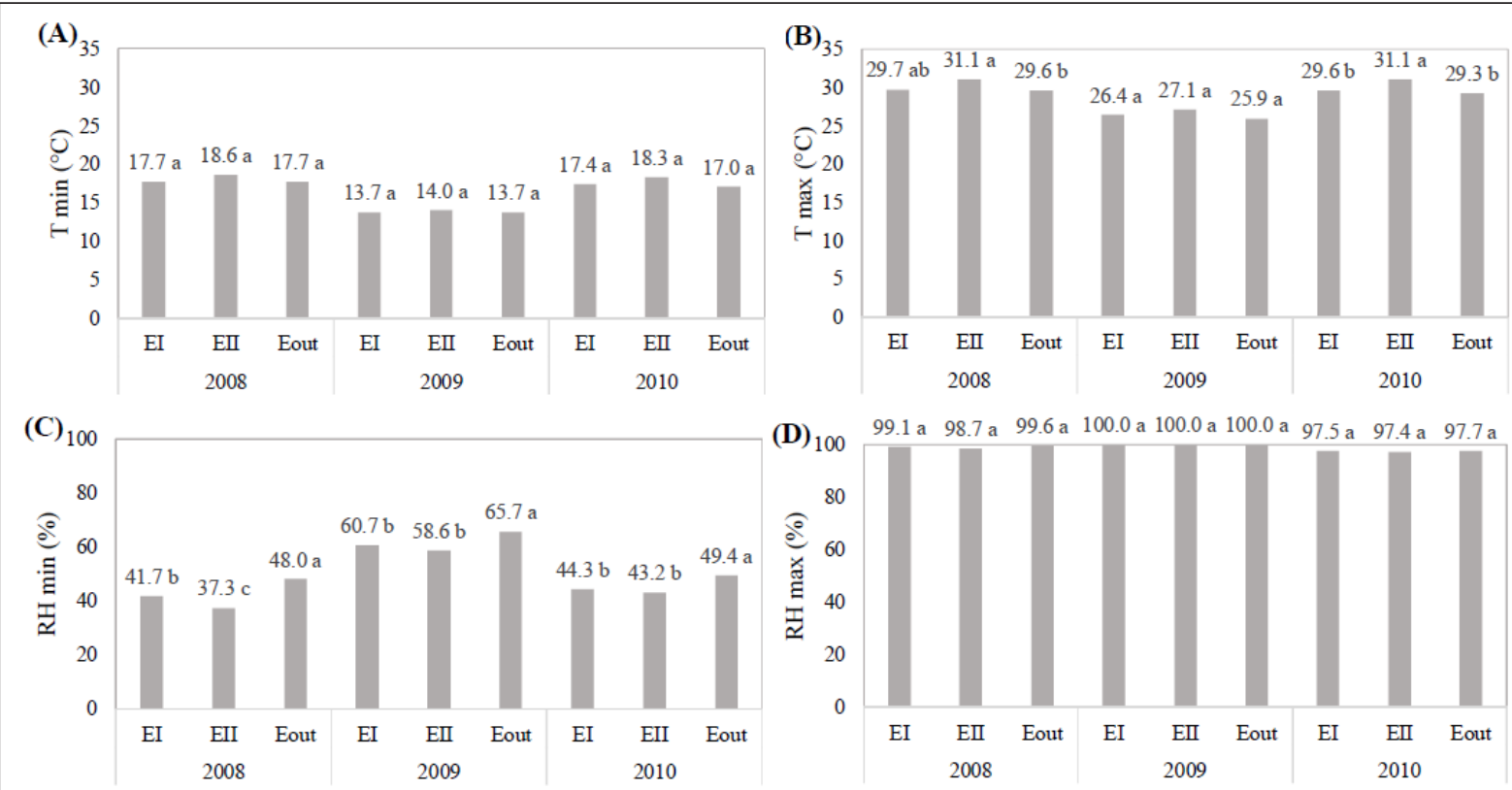

Figure 2 - Minimum and maximum air temperature (T min; T max) and relative humidity (RH min; RH max) during the growth periods of tomato $(2008,2009$ and 2010) in the Environment I (EI) = polyethylene anti-UV + thermo-reflective screen, Environment II $($ EII $)=$ diffusive plastic screen, and outside (E out). *For each period separately, averages followed by different letters differ statistically from each other by Kruskal-Wallis's test $(\mathrm{P}<0.05)$.

observed for 11, 7 and 14 days in EI, for 21, 13 and 39 days in EII, and 10, 0 and 7 days outside, respectively in 2008, 2009 and 2010.

Regarding the RH values, the optimal for vegetable crops should be above $40 \%$ (ANDRIOLO, 2002). RH varied from $30.6 \%$ (RHmin) to $99.1 \%$ (RHmax) in 2008, while in 2009 and 2010 the values ranged respectively from 29.7 to $100 \%$ and from 16.1 to $97.2 \%$ (Figure 3 ). The largest fluctuations occurred for RHmin. The daily RHmax values were always close to $100 \%$ in most of the three growing seasons. It was reported that in EI occurred 37, 47, 82 days in which RH was lower than 40\%, respectively for 2008, 2009 and 2010 growing seasons. In the EII, there were 53, 68 and 87 days with RH lower than $40 \%$, respectively for the same years.

Tomato plants under EII, considering the three growing seasons, had, in general, better production indices than under EI (Table 1), with higher total productivity (TP) and total of fruits in all categories (Table 1). This better performance of the plants grown under EII is justified by the higher availability of solar energy inside EII than EI. The photosynthetically active radiation (PAR) in EII was, on average, 92.8\% higher than PAR observed under EI (Figure 1). Such results agree with the relationship obtained by COCKSHULL et al. (1992), which considered that an increase of $1 \%$ in the PAR provided approximately an increase of $1 \%$ on tomato yield. Besides, the diffusive radiation promoted by EII reduced shading between plants, improving the SR absorption efficiency by them (SINCLAIR et al., 1992). PINHEIRO (2016), in Piracicaba (SP), evaluating the cv. 'Sweet Grape' productivity under greenhouse covered with double anti-UV polyethylene, also observed the effect of increased light availability on crop yield, but using LED modules as light supplementation.

Regarding the cultivars performance under greenhouse (Table 1), the cv. 'Sweet Grape' presented lower averages than cv. 'Sweet Million' for almost all quantitative characteristics, resulting in a total fruit productivity per plant (TP) $13 \%$ lower in comparison to the other cultivar. CAMPAGNOL (2015), studing cv. 'Sweet Grape' under greenhouse covered with 


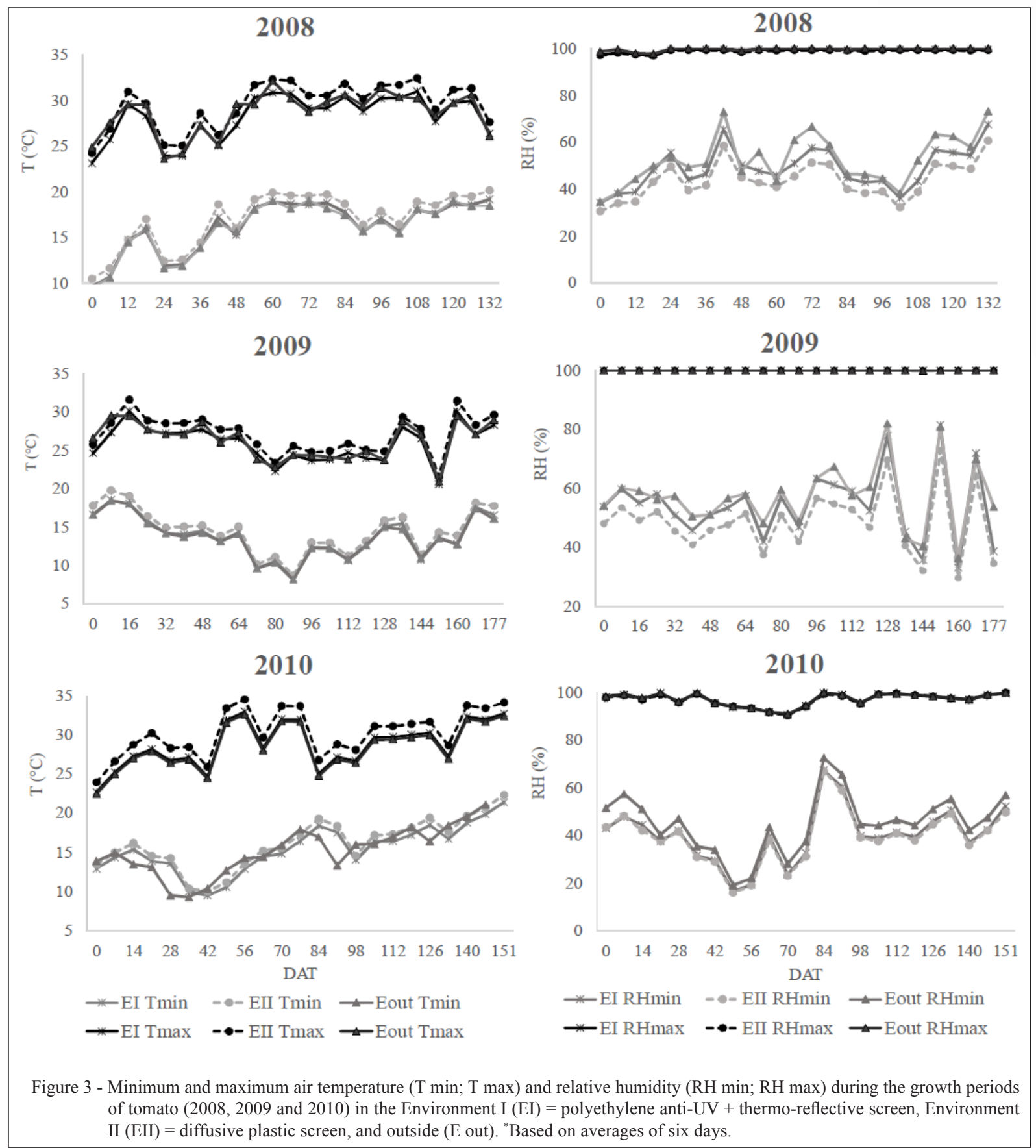

double polyethylene film (anti-UV), obtained results for fruit weight similar to those presented in table 1 (SFW, LFW). Considering the fruit size classification determined in the present study, this author obtained averages of 4.2 and $12.0 \mathrm{~g}$ for small and large fruits weight, respectively; however, with a total productivity per plant (TP) higher than observed in the present study, of $6.67 \mathrm{~kg}$.

The SP, TP, NTF and SFW were higher in 2008 than 2010 in both environments, probably due to the plastic degradation (Table 1). The SR transmissivity varies as a function time use of 
Table 1 - Small fruit productivity (SP, $\left.\mathrm{kg} \mathrm{plant}^{-1}\right)$, large fruit productivity (LP, $\left.\mathrm{kg} \mathrm{plant}^{-1}\right)$, total fruit productivity (TP, $\left.\mathrm{kg} \mathrm{plant}^{-1}\right)$, number of small fruit (NSF, $\mathrm{n}^{\mathrm{o}}$ plant $\left.{ }^{-1}\right)$, number of large fruit (NLF, $\mathrm{n}^{\mathrm{o}}$ plant $\left.{ }^{-1}\right)$, number of total fruit $\left(\mathrm{NTF}, \mathrm{n}^{\mathrm{o}}\right.$ plant-1), small fruit weight (SFW, g fruit-1) and large fruit weight (LFW, g fruit-1) of two cherry tomatocultivars grown in two environments (E) and three periods $(\mathrm{P})$.

\begin{tabular}{|c|c|c|c|c|c|c|c|c|}
\hline Main factors & SP & LP & $\mathrm{TP}$ & NSF & NLF & NTF & SFW & LFW \\
\hline \multicolumn{9}{|c|}{ 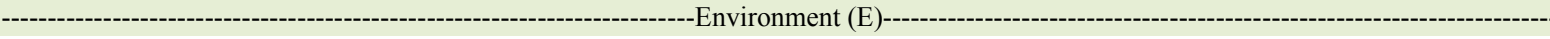 } \\
\hline Thermo-reflective screen - EI & $0.54 \mathrm{~b}$ & $2.84 \mathrm{~b}$ & $3.37 \mathrm{~b}$ & $121.7 \mathrm{~b}$ & $282.0 \mathrm{~b}$ & $403.7 \mathrm{~b}$ & $4.92 \mathrm{~b}$ & $11.67 \mathrm{a}$ \\
\hline Diffusive plastic - EII & $0.78 \mathrm{a}$ & $4.06 \mathrm{a}$ & $4.84 \mathrm{a}$ & $176.8 \mathrm{a}$ & 389.7 a & $566.5 \mathrm{a}$ & $5.13 \mathrm{a}$ & $12.16 \mathrm{a}$ \\
\hline \multicolumn{9}{|c|}{ 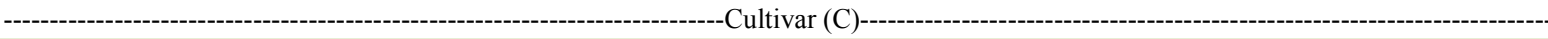 } \\
\hline 'Sweet Million’ & $0.62 \mathrm{a}$ & $3.78 \mathrm{a}$ & $4.39 \mathrm{a}$ & $128.9 \mathrm{~b}$ & $365.7 \mathrm{a}$ & $494.6 \mathrm{a}$ & $5.42 \mathrm{a}$ & $12.57 \mathrm{a}$ \\
\hline 'Sweet Grape' & $0.70 \mathrm{a}$ & $3.12 \mathrm{~b}$ & $3.82 \mathrm{~b}$ & 169.7 a & $306.0 \mathrm{~b}$ & $475.6 \mathrm{a}$ & $4.63 \mathrm{~b}$ & $11.27 \mathrm{~b}$ \\
\hline \multicolumn{9}{|c|}{ Period $(\mathrm{P})$} \\
\hline 2008 & $1.29 \mathrm{a}$ & $3.15 \mathrm{~b}$ & $4.42 \mathrm{a}$ & $231.2 \mathrm{a}$ & $308.3 \mathrm{~b}$ & $539.5 \mathrm{a}$ & $6.39 \mathrm{a}$ & $11.69 \mathrm{a}$ \\
\hline 2009 & $0.47 \mathrm{~b}$ & $3.25 \mathrm{~b}$ & $3.72 \mathrm{~b}$ & $149.4 \mathrm{~b}$ & $347.9 \mathrm{ab}$ & $497.3 \mathrm{a}$ & $5.13 \mathrm{~b}$ & $12.49 \mathrm{a}$ \\
\hline 2010 & $0.22 \mathrm{c}$ & $3.96 \mathrm{a}$ & $4.17 \mathrm{ab}$ & $67.2 \mathrm{c}$ & $351.4 \mathrm{a}$ & $418.6 \mathrm{~b}$ & $3.55 \mathrm{c}$ & $11.57 \mathrm{a}$ \\
\hline \multicolumn{9}{|c|}{ 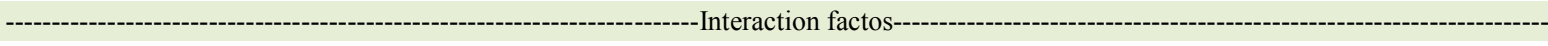 } \\
\hline $\mathrm{E} \times \mathrm{C}$ & ns & ns & ns & ns & ns & ns & ns & ns \\
\hline ExP & * & ns & ns & ** & ns & ns & * & ns \\
\hline $\mathrm{C} \times \mathrm{P}$ & ns & ns & ns & ns & ns & ns & ** & ns \\
\hline$E \times C \times P$ & $\mathrm{~ns}$ & ns & ns & $\mathrm{ns}$ & ns & ns & ns & ns \\
\hline CV (\%) & 39.18 & 13.67 & 16.47 & 27.49 & 15.68 & 16.44 & 6.65 & 8.24 \\
\hline
\end{tabular}

For each main factor separately, averages followed by different letters in the same column differ statistically from each other by Tukey's test $(\mathrm{P}<0.05)$.

plastic, changing the energy balance within the environments. Consequently, small differences in the SR transmissivity on the covering material can have a significant effect on crops growth and development (KITTAS et al., 1999), directly involving reduction of PAR transmitted to the covered environment. This can be evidenced in table 2 , by analyzing the variable 'Period' $(\mathrm{P})$. There was a significant decrease of average values for NSF and SFW, and directly affected the SP. However, this fact did not change the total productivity (TP), comparing the evaluated years. For the large fruits (LP, NLF and LFW), the plastic effect was not significant.

\section{CONCLUSION}

Based on that, the use of diffusive plastic in greenhouses can be recommended for southern Brazil, since it provides a better inside distribution of solar energy without causing major changes in air temperature and relative humidity, resulting in higher tomato productivity and fruit size than

Table 2 - Statistical interaction between 'Environment' (E) and 'Period' (P) for small fruit productivity (SP, $\left.\mathrm{kg} \mathrm{plant}^{-1}\right)$, number of small fruit $\left(\mathrm{NSF}, \mathrm{n}^{\mathrm{o}}\right.$ plant $\left.^{-1}\right)$ and small fruit weight $\left(\mathrm{SFW}, \mathrm{g}\right.$ fruit $\left.{ }^{-1}\right)$; and between 'Cultivar' (C) and 'Period' (P) for SFW: [Environment I (EI) $=$ polyethylene anti-UV + thermo-reflective screen; Environment II (EII) = diffusive plastic screen].

\begin{tabular}{|c|c|c|c|c|c|c|c|c|}
\hline \multirow{2}{*}{ Period (P) } & \multicolumn{4}{|c|}{---------------NSF-------------- } & \multicolumn{2}{|c|}{--------------SFW-------------- } & \multicolumn{2}{|c|}{---SFW--. } \\
\hline & EI & EII & EI & EII & EI & EII & Million & Grape \\
\hline 2008 & $1.02 \mathrm{aA}$ & $1.56 \mathrm{aA}$ & $180 \mathrm{aA}$ & $282 \mathrm{aA}$ & $6.1 \mathrm{aA}$ & $6.6 \mathrm{aA}$ & $6.7 \mathrm{aA}$ & $6.1 \mathrm{aA}$ \\
\hline 2009 & $0.41 \mathrm{bA}$ & $0.54 \mathrm{bA}$ & $123 \mathrm{abA}$ & $173 \mathrm{abA}$ & $5.2 \mathrm{aA}$ & $5.1 \mathrm{abA}$ & $5.9 \mathrm{bA}$ & $4.4 \mathrm{bB}$ \\
\hline 2010 & $0.20 \mathrm{bA}$ & $0.25 \mathrm{cA}$ & $60 \mathrm{bA}$ & $75 \mathrm{bA}$ & $3.5 \mathrm{bA}$ & $3.6 \mathrm{bA}$ & $3.7 \mathrm{cA}$ & $3.4 \mathrm{cA}$ \\
\hline
\end{tabular}

For each biometric variable separately, averages followed by different lowercase letters in the same column and by different capital letters in the same line, differ statistically from each other by Tukey's test $\left({ }^{*} \mathrm{P}<0.05\right)$. 
those obtained in thermo-reflective screen plastic associated to anti-UV.

\section{ACKNOWLEDGEMENTS}

The authors are grateful to Polysack Plastic Industries Ltda for supplying the shading screens and to Fundação de Amparo à Pesquisa do Estado de São Paulo (FAPESP) for supporting this project (Process $n^{\circ}$ : 2008/58624-1) and the first author with a master scholarship (Process $n^{\circ}:$ 2007/57897-1).

\section{REFERENCES}

ADAMS, S.R. et al. Effect of temperature on the growth and development of tomato fruits. Annals of Botany, v.88, p.869-877, 2001. Available from: <https://doi.org/10.1006/anbo.2001.1524>. Accessed: Aug. 15, 2016. doi: 10.1006/anbo.2001.1524.

ALVARENGA, M.A.R. Produção de tomate em campo, em casa de vegetação e em hidroponia: origem, botânica e descrição da planta. Lavras: UFV, 2004. 18p.

ANDRIOLO, J.L. Olericultura geral: princípios e técnicas. Santa Maria: UFSM, 2002. 158p.

ARAUJO, L. et al. Cherry tomato grown in differen concentrations of nutrient solution in hydroponic capillary. Unimontes Científica, v.15, n.1, p.18-27, 2013. Available from: <http://ruc.unimontes.br/index.php/unicientifica/article/ view/131>. Accessed: Apr. 12, 2016.

BAILLE, A. et al. Characterization of the solar diffuse component under "parral" type greenhouses. Acta Horticulturae, n.614, p.341-346, 2003. Available from: <https://doi.org/10.17660/ ActaHortic.2003.614.51>. Accessed: Mar. 07, 2016. doi: 10.17660/ ActaHortic.2003.614.51.

CAMPAGNOL, R. Nitrogen and substrate in nutritional management, yield and quality of tomato growth in climated greenhouse. 2015. 95p. Thesis (Doctorate in Phytotechnology) - Postgraduate Course in Phytotechnology, Luiz de Queiroz College of Agriculture, University of São Paulo, SP. Available from: $\quad<$ http://www.teses.usp.br/teses/disponiveis/11/11136/ tde-28042015-170342/en.php>. Accessed: Jun. 02, 2017. doi: 10.11606/T.11.2015.tde-28042015-170342.

COCKSHULL, K.E. et al. The influence of shading on yield of glasshouse tomatoes. Journal of Horticultural Science, v.67, n.1, p.11-24, 1992. Available from: <http://dx.doi.org/10.1080/002215 89.1992.11516215>. Accessed: Jul. 17, 2016. doi: 10.1080/00221 589.1992 .11516215$.

DUARTE, L.A. et al. Changes in air temperaturee due to side screens of greenhouses cultivated with tomato. Revista Brasileira de Engenharia Agrícola e Ambiental, v.15, n.2, p.148-153, 2011. Available from: <http://dx.doi.org/10.1590/S141543662011000200006>. Accessed: Jul. 21, 2016. doi: 10.1590/ S1415-43662011000200006.

FOOD AND AGRICULTURE ORGANIZATION OF THE UNITED NATIONS (FAO). Protected cultivation in the Mediterranean climate. Roma, 1990. 313p. (Plant Production and Protection Paper, 90).
FERNANDES, C. et al. Impact of four substrates and fertigation parceling on tomato yield in greenhouse conditions. Horticultura Brasileira, v.20, n.4, p.559-563, 2002. Available from: <http://dx.doi.org/10.1590/S010205362002000400010>. Accessed: Jul. 25, 2016. doi: 10.1590/ S0102-05362002000400010

FERRARI, D.L.; LEAL, P.A. Use of thermoreflective screens on greenhouses for tomato production. Engenharia Agrícola, v.35, n.2, p.180-191, 2015. Available from: <http://dx.doi. org/10.1590/1809-4430-Eng.Agric.v35n2p180-191/2015>. Accessed: Aug. 15, 2016. doi: 10.1590/1809-4430-Eng.Agric. v35n2p180-191/2015.

FINCH, D.A. et al. Photosynthetically active radiation regimes in a southern African savanna environment. Agricultural and Forest Meteorology, v.122, p.229-238, 2004. Available from: <https:// doi.org/10.1016/j.agrformet.2003.09.015>. Accessed: Mar. 16, 2016. doi: 10.1016/j.agrformet.2003.09.015.

GARCÍA, M.L. et al. Climatic effects of two cooling systems in greenhouses in the Mediterranean area: external mobile shading and fog system. Biosystems Engineering, v.108, p.133-143, 2011. Available from: <https://doi.org/10.1016/j. biosystemseng.2010.11.006>. Accessed: Mar. 16, 2016. doi: 10.1016/j.biosystemseng.2010.11.006

GUISELINI, C. et al. Greenhouse cover management: solar radiation effects on production and quality of a gerbera crop. Revista Brasileira de Engenharia Agrícola e Ambiental, v.14, n.6, p.645-652, 2010. Available from: <http://dx.doi.org/10.1590/ S1415-43662010000600011>. Accessed: Jun. 08, 2016. doi: $10.1590 / \mathrm{S} 1415-43662010000600011$.

KITTAS, C. et al. Influence of covering material and shading on the spectral distribution of light in greenhouse. Journal of Agricultural Engineering Research, v.73, p.341-351, 1999. Available from: <https://doi.org/10.1006/jaer.1999.0420>. Accessed: Jun. 06, 2016. doi: 10.1006/jaer.1999.0420.

MAHAJAN, G.; SINGH, K.G. Response of greenhouse tomato to irrigation and fertigation. Agricultural Water Management, v.84, p.202-206, 2006. Available from: <https://doi.org/10.1016/j. agwat.2006.03.003>. Accessed: Jun. 13, 2016. doi: 10.1016/j. agwat.2006.03.003.

PINHEIRO, R.R. Light supplementation on tomato cultivated in different management systems in greenhouse. 2016. 97p. Thesis (Doctorate in Phytotechnology) - Postgraduate Course in Phytotechnology, Luiz de Queiroz College of Agriculture, University of São Paulo, SP. Available from: <http://www.teses. usp.br/teses/disponiveis/11/11136/tde-05072016-175012/en.php>. Accessed: Jun. 02, 2017.

PRECZENHAK, A.P. et al. Agronomic characterization of minitomato genotypes. Horticultura Brasileira, v.32, p.348356, 2014. Available from: <http://dx.doi.org/10.1590/S010205362014000300018>. Accessed: Apr. 13, 2016. doi: 10.1590/ S0102-05362014000300018.

REBOUÇAS, P.M. et al. Radiação solar e temperatura do ar em ambiente protegido. Revista Agrogeoambiental, v.7, n.2, p.115125, 2015. Available from: <http://dx.doi.org/10.18406/23161817v7n22015610>. Accessed: Apr. 13, 2016. doi: 10.18406/23161817 v7n22015610. 
REIS, L.S. et al. Leaf area index and productivity of tomatoes under greenhouse conditions. Revista Brasileira de Engenharia Agrícola e Ambiental, v.17, n.4, p.386-391, 2013. Available from: <http://dx.doi.org/10.1590/S1415-43662013000400005> Accessed:Apr. 13, 2016. doi: 10.1590/S1415-43662013000400005.

ROSALES, M.A. et al. The effect of environmental conditions on nutritional quality of cherry tomato fruits: evaluation of two experimental Mediterranean greenhouses. Journal of the Science of Food and Agriculture, v.91, n.1, p.152-162, 2011. Available from: < http://onlinelibrary.wiley.com/doi/10.1002/jsfa.4166/full>. Accessed: Apr. 14, 2016. doi: 10.1002/jsfa.4166.

ROSALES, M.A. et al. Antioxidant content and ascorbate metabolism in cherry tomato exocarp in relation to temperature and solar radiation. Journal of the Science of Food and Agriculture, v.86, p.1545-1551, 2006. Available from: <http://onlinelibrary.wiley.com/doi/10.1002/ jsfa.2546/full>. Accessed: Apr. 14, 2016. doi: 10.1002/jsfa. 2546.

SENTO-SÉ, G.V.T. et al. Performance of mini tomatoes cultivars in summer conditions of Sumedium Valley of São Francisco River. In: Embrapa Semiárido-Artigo Annals of congress (ALICE) Horticultura Brasileira, v.31, n.2, p. S1017-S1022, 2014.

SERRANO, T.D. et al. Los filmes plásticos en la producción agrícola. Madrid: Mundi-Prensa, 2001. 318 p.
SILVA, J.D.; GIORDANO, L.D.B. Tomate para processamento industrial. Brasília: Embrapa Comunicação para Transferência de Tecnologia-Embrapa Hortaliças, 2000. 168 p.

SILVA, B.A. et al. Cultivo protegido. Em busca de mais eficiência produtiva. Hortifruti Brasil, n.132, p.10-18, 2014.

SINCLAIR, T.R. et al. Variation in crop radiation-use efficiency with increased diffuse radiation. Crop Science, v.32, p.12811284, 1992. Available from: <https://dl.sciencesocieties.org/ publications/cs/abstracts/32/5/CS0320051281>. Accessed: Mar 21, 2016. doi: 10.2135/cropsci1992.0011183X003200050043x.

SOARES, I. et al. Volume effect of nutritive solution on the production and nutrition of cherry tomato plants cultivated in substrate. Revista Ciência Agronômica, v.36, n.2, p.152-157, 2005. Available from: <http://www.redalyc.org/ html/1953/195317396005/>. Accessed: Apr. 14, 2016.

STANGHELLINI, C. et al. Effect of near-infrared-radiation reflective screen materials on ventilation requirement, crop transpiration and water use efficiency of a greenhouse rose crop. Biosystems Engineering, v.110, p.261271, 2011. Available from: <https://doi.org/10.1016/j. biosystemseng.2011.08.002>. Accessed: Apr. 14, 2016. doi: 10.1016/j.biosystemseng.2011.08.002. 